\title{
Sosyal Politika, Yoksulluk ve Kent Yoksulluğu
}

\author{
DOI: 10.26466/opus. 708198
}

*

\author{
Eylem Beyazit* \\ * Dr. Öğretim Üyesi, Hatay Mustafa Kemal Üniversitesi, Antakya M.Y.O, Yerel Yönetimler \\ Programi/Hatay/Türkiye \\ E-Posta: eylmbyzt@gmail.com \\ ORCID: $\underline{0000-0002-3432-5722}$
}

\begin{abstract}
Öz
Sosyal politikanın en tartışmalı alanlarından biri yoksulluktur. Yoksulluğun sosyal politika alanında ele alınışı ve akademik bulgular, yoksulluğun uzun bir süre daha sosyal politikanın önemli bir sorun alanı olacağını göstermektedir. Sosyal devlet, refah devleti ve liberalizmin yeni yaklaşımları arasında tartışmalar sürerken küreselleşme ile özellikle yoksulluğun hem boyutunun hem de niteliğinin değiştiği bilinmektedir. Kent yoksulluğu ve kent yoksulluğunun değişen halleri, giderek kentlerde toplanan dünya nüfusu düşünüldü̈̆̈̈̈nde, kamusal hizmetlere etkin ulaşım açısından yönetimleri şimdiden yeni kamu politikalar üretmeye ve uygulamaya yönlendirmektedir. Bu çalışmanın temel amacı sosyal politikanın ne olduğundan yola çıkarak yoksulluk ve kent yoksulluğunu tartışmaktır. Ayrica, gelecekte kent yoksulluğu üzerinden üretilecek yeni yoksulluk süreçlerini şimdiden anlamak ve değerlendirmek önemlidir. Günümüzde nüfusun kıra oranla giderek kentlerde yoğunlaşması özellikle kent yoksulluğunun derinleşmesine neden olmaktadır. Geleceğin kentlerini derinleşen kent yoksulluğu üzerinden yeniden okuyup anlamaya çalışmak, kapsayıcı sosyal politikaların oluşturulması için sağllklı bir zemin oluşturacaktır. Sosyal politika ve yoksulluk çerçevesinde, kent yoksulluğu ve kent yoksulluğunun dönüşümü ile ilgili tartışmalar gösteriyor ki yakın zamanda ideolojik tartışmaları da aşan ortak bir sorun alanı olarak kent yoksulluğu, geleceğin kentleri ve yönetimleri bakımından temel belirleyici olacaktır.
\end{abstract}

Anahtar Kelimeler: Sosyal politika, yoksulluk, kent yoksulluğu 


\title{
Social Policy, Poverty and Urban Poverty
}

\begin{abstract}
One of the most polemical areas of social policy is poverty. Poverty studies in the social policy domain and academic results show that poverty will remain for a long time a significant problem area. While debates continue between theories of the social state, of the welfare state and the new approaches of liberalism, it is known that dimension and property of poverty have changed with globalization. Urban poverty and the shifting urban poverty states, considering population that is increasingly gathered in cities, lead governments to produce and implement new public policies in terms of access effectively to public services. The main purpose of this study is to discuss poverty and urban poverty within the framework of social policy meaning. Moreover, it is essential to understand and examine the new poverty processes that will be produced in the future through urban poverty. Nowadays, the concentration of the population in urban rather than rural areas causes the urban poverty to deepen. Trying to re-understand the urban of the future through deepening urban poverty will create a reasonable basis for the establishment of inclusive social policies. The discussions on social policy and the shift of urban poverty demonstrate that urban poverty will be the main determinant of the urban of the future and urban management as a common problem area that transcends the ideological disagreement.
\end{abstract}

Keywords: Social policy, poverty, urban poverty 


\section{Giriş}

Toplum yapısını açıklamaya yönelik düşüncelerin insanlık tarihi kadar eski olduğu herkes tarafından bilinmektedir. Aristo'dan Platon'a kadar uzanan bu düşün tarihi, 18. yüzyıldan sonra Avrupa'da yaşanan Fransız İhtilali ve Sanayi Devrimi'nin yaratmış olduğu dinamiklerinde etkisiyle, insanların yaşama, düşünme ve çalışma şartlarındaki değişiklikleri de içinde barındırmaktadır. Sosyal politika işte bu dönemde ortaya çıkmış ve gelişmiştir. Sosyal politikaları şekillendirecek en önemli olgulardan biri olan yoksulluk da karmaşıklaşan, değişen ve zaman içinde kuşaktan kuşağa farklılık gösteren bir olgu olarak sosyal politika alanının odak noktasındadır. Toplumsal değişim ve dönüşümlerin hızlı yaşandığı ve gelir dağılımındaki adaletsizliklerin derinleştiği zamanlarda yoksulluk daha yoğun bir şekilde kendini göstermektedir. Kapitalizmin küreselleşmesi ile gelir düzeylerindeki farkl1laşma ve buna bağlı olarak yaşam standartlarının değişmesi ve nihayetinde kırdan kente ve sanayileşmiş ülkelere göç yeni yoksulluk biçimlerinin ortaya çıkmasına neden olmuştur. Yoksulluk, ülkelerin ve içinde yer aldıkları coğrafyanın tarihsel ve özgün koşullarının yanı sıra, kapitalizmdeki eşitsiz gelişmenin ve yarattı̆̆ krizlerinin bir sonucu olarak farklı boyut ve şiddetlerde tüm dünyada yaşanmaktadır (Sallan Gül, 2001, s.1).

Dünyada gittikçe artan gelir dağılımı eşitsizlikleri ve işsizlikle birlikte daha sık yaşanmaya başlanan ekonomik krizler nedeniyle yoksulluk giderek artmaktadır. Derinleşen bu olgu kentlerin mekânlarına da farklı boyutlarıyla yansımaktadır. Yoksullar kent çeperleriyle kentin mekânsal dışlanmışlıklarına doğru bir yaşama sürüklenmektedir. Bölgeler arası eşitsizlikler, sanayi, ticaret ve turizmde öne çıkan kentlere doğru bir göç akışına neden olmakta ve bu göçler sonucunda ortaya çıkan yeni kent yoksulları sorunlarına formel olmayan yollardan çözüm aramaktadırlar. Yasal olmayan bir şekilde konut sorununu gecekondular inşa ederek çözmeye çalışan bu kesim aynı zamanda enformel işlere de yönelmektedirler.

Bu çalışma sosyal politikanın ne olduğundan yola çıkarak kavramın gelişimini yoksulluk ve kent yoksulluğunu üzerinden tartışmayı amaçlamaktadır. Gelecekte kent yoksulluğu üzerinden üretilecek yeni yoksulluk süreçlerini bugünden anlamak ve değerlendirmek sürecin yönetimi açısından oldukça önem taşımaktadır. Günümüzde nüfusun kıra oranla giderek kentlerde yoğunlaşması özellikle kent yoksulluğunun derinleşmesine neden 
olmaktadır. Geleceğin kentlerini derinleşen kent yoksulluğu üzerinden yeniden okuyup anlamaya çalışmak, kapsayıcı sosyal politikaların oluşturulması için sağlıklı bir zeminin oluşmasına katkıda bulunacaktır.

\section{Sosyal Politika Kavramı ve Gelişimi}

Kavramsal açıdan bakıldığında sosyal politikayı devlet toplum ilişkisi bağlamında devlete düşen bütün kararlar ve uygulamalar demeti olarak tanımlamak mümkündür. Doğal olarak kavram, söz konusu kararların uygulanması kadar sürdürülebilir olmasını da içerir.

Sosyal politika, topluma ve onun örgütlenmesine dair sınıfsal ilişkiler, çelişkiler ve çatışmalar karşısında esasen düzeni de ayakta tutmaya çalışan bir disiplin olarak değerlendirilmektedir (Talas, 1992, s.15). Laubier (aktaran Koray ve Topçuoğlu, 1995, s.2) sosyal politikanın, dönemsel-toplumsal değişimler karşısında, maddi ve manevi olarak toplumun yeniden inşasında alınan önlemleri de kapsadığını ileri sürer.

Sanayi devrimi sosyal politika için bir milattır. Dolayısıyla kavramı anlamak ve anlamlandırmak için sanayi devrimi ve sanayi devrimi sonrası yaşanan gelişmeleri iyi çözümlemek gerekir (Beyazıt ve Güneş, 2016, s.81). Özellikle Sanayi Devrimi ile birlikte insan hayatının her alanında alt üst oluşlar yaşanmıştır. 19. yüzyıl bu anlamda sadece bilimsel alanda değil aynı zamanda sosyal çalkantılar açısından da hareketliliğin yaşandığı bir yüzyıl olmuştur. Şöyle ki; sanayileşme ile batı dünyasının yaşamı değişmekte, sosyal patlamalar birbirini kovalamakta ve geleneksel siyasal ve sosyal düzen temelden sarsilmaktaydı (Aybar, 2002, s.35).

Sosyal politikaların gösterdiği gelişimde 1. Dünya Savaşı sonrası 1919 yılında Versay Barış Antlaşması uyarınca kurulan ve çalışma koşullarının dünya ölçeğinde bir standarda bağlanması için sözleşmeler üretmeği amaçlayan Uluslararası Çalışma Örgütü (ILO), sosyal politikaların ulus ötesi bir çerçeveye oturup kavramlaşmasına liderlik etmiştir. Dünya barışı için sosyal adaletin gerekliliği anlayışıyla kurulan ILO, kuruluşuyla birlikte hızlı bir kural üretme sürecine girmiş ve ivedilik taşıyan bireysel çalışma ilişkilerini düzenlemeye odaklanmıştır (Çolak, 2019, s.73). 1929'da yaşanan ekonomik bunalım ve yarattığı sorunlar, kamu politikalarını öne çıarmıştır. Sosyal politikaların önem kazandığı sosyal devlet anlayışı da artık bu dönemden sonra hem teoride hem de uygulamada kendini göstermiştir. 
Sosyal politika kavramını literatüre kazandıran düşünür Wilhelm Heinrich Riehl'dir. 19. yüzyılın ikinci yarısına denk gelen bu dönem iş̧̧i sınıfının içinde bulunduğu koşullar ile yaşadıkları zorluklar ve bu zorlukların nasıl düzeltilmesi gerektiğinin tartışıldığı bir dönem olması nedeniyle sosyal politikayı tanımlayan dar bir alana karşılık gelmektedir. Başlangıçta sosyal politika alanı, işçiyi koruma, toplu iş uyuşmazlıklarını önleme, düzenleme ve işçiye firsatlar sağlama konularında yoğunlaşmış ve bu görevin de demokrasinin denetimi altında devlet tarafından gerçekleştirilmesi hedefi benimsenmiştir (Esin, 1982, s.133). Kavramın daha geniş anlamıyla tartışılması ve dar anlamdan sıyrılıp geniş anlamlı bir sosyal politika kavramını içermesi belli bir süreç dâhilinde olmuştur.

Sosyal politikanın konusunu yoksulluk başta olmak üzere sosyal güvenlik önlemleri ve çalışma hayatının düzenlenmesi gibi sorun alanları oluşturmaktadır. Buğra ve Keyder (2008)'e göre, temel sorunların bir sosyal sorun haline gelip değerlendirmeleri için kapitalizmin doğuşu ve gelişimini beklemek gerekmiştir. Bununla birlikte 16. yüzyıldan itibaren bir takım sosyal sorunların kapitalizm öncesi dönemden itibaren ele alındığ 1 bilinmektedir. İlk yoksulluk yasaları İngiltere'de 1. Elizabeth Dönemi'nde yürürlüğe girmiş; Avrupa'da yoksulluğun durumunu anlamaya yönelik istatistiki veri toplama çabaları daha öncelere uzanmıştır. Diğer alanlardaki sorunlar ise tarihsel olarak 18. yüzyıldan itibaren ağırlık kazanmaya başlamıştır. Bugünkü anlamıyla sosyal güvenlik önlemleri ise, 19. yüzyllın ikinci yarısından itibaren İngiltere'den önce Kıta Avrupası'nda gündeme gelmiştir (Buğra ve Keyder, 2008, s.9-10). Artık sosyal politika, işçi sınıfını da aşan ve toplumun bütün kesimlerini ilgilendiren bir alan halini almıştır (Güven, 1996, s.1).

\section{Ekonomik ve Sosyal Düşünce Sistemlerinde Sosyal Politika}

Temellerini Adam Smith'in attığı ve sonra David Ricardo ve Thomas Malthus'un katkılarıyla biçimlenen "Klasik Liberalizm" yaklaşımı ekonomik ve toplumsal yaşantıyı yarattı̆̆ varsayılan doğal düzene her türlü müdahaleyi reddetmektedir. Bu düşüncede piyasa, her sorun için kendiliğinden bir çözüm olarak görülmektedir. Klasik liberal düşüncede piyasa mekanizması ve fiyatlar sistemi her türlü ekonomik ve sosyal sorunu kendiliğinden çözümleyen "gizli bir el" işlevi görmektedir. Girişimcilerin çıkarları ile toplumun 
çıkarları örtüştüğünden dolayı sosyal sorunlarla karşılaşılmayacak ve bu nedenle devlet ekonomik ve sosyal hayata müdahale etmek durumunda kalmayacaktır (Güven, 2001, s.52-53). Klasik liberaller, devlet müdahalesinin sinırlı olması durumunda, piyasanın, geçici bir olgu olan yoksulluk durumunu uzun vadede ortadan kaldıracağını iddia ederler. Dolayısıyla Adam Smith'e göre yoksulluk liberalizm için süregelen bir olgu değildir; aksine "doğal ayıklanma" sürecidir. Dolayısıyla akımın temsilcileri, özellikle dışlanmış yoksul kesim için yardımları reddederler (Malthus, 1998). Toplumu yaşayan bir organizma olarak gören Spencer (2016) "doğal ayıklanma" kavramını daha ileriye taşıyarak "en uygun olanın hayatta kalması"nı toplumsal yaşama uyarlar. Heywood (2013, s.67)'a göre de toplum, söz konusu kesimler için "yaşam mücadele alanı"dır.

Ayrımsız her türlü devlet müdahalesini kabul etmeyen klasik liberal düşünce için piyasa temel kabuldür. Klasik liberal düşünce, ortaya çıkan ekonomik olumsuzluklar ve büyüyen işçi sınıfının etkisiyle 19. yüzyılın ikinci yarısından itibaren yeni bir yapılanma sürecinin içine girmiştir. Özellikle işçilerin ağır çalışma koşulları ve sisteme nasıl entegre olacakları sorusuna yanit aranması, liberal geleneğin yeniden yorumlanarak sosyal ve pozitif bir nitelik kazanmaya başlamasına neden olmuş ve bu durum "Sosyal Liberalizm" şeklinde tanımlanmıştır. Bunun öncüsü de Kant ve Hegel'in felsefelerinden etkilenen Hill Green olmuştur. Green, pozitif özgürlük anlayışı ile devlete yeni görevler yükleyen ve aktif görevlerle bunu destekleyen liberal bir düşünce kurgusuyla; bireyin toplum içinde üretken değerlerden pay alması gerekliliğine ve devletin bu konudaki sorumluluğuna dikkat çekmiştir (Erdoğan, 1998, s.11).

Klasik liberal anlayışın piyasa mekanizması ve bireycilik esaslarını kabul eden sosyal liberaller, piyasada oluşan eşitsizliklerin önlenmesi gereken bir durum olduğu düşüncesini savunmaktadırlar. Sosyal liberal düşünce, her ne kadar Keynesyen düşünce ve uygulamalara dayansa da, ilk olarak İngiltere'de 1908 Asquith hükümetinin ve 1932'de ABD'de Roosevelt hükümetinin programlarında yer almıştır. 2. Dünya Savaşı ve petrol krizlerine kadar da Avrupa'da sağlanan uzlaşının temeli olmuştur. Kapitalizm bir yandan işleyişi ile zenginliklerin kaynağını oluştururken, diğer yandan yaşanan aksaklıklar devlet müdahaleleri ile bertaraf edilmeye çalışılmış özellikle batılı ülkelerde çözüm olarak Keynesyen yaklaşımın yani "Refah Devleti” 
anlayışının gelişmesi ve güçlenmesine olanak sağlanmıştır (Koray ve Topçuoğlu, 1995, s.54; Sallan Gül, 2006, s.33-34).

Sosyal liberal düşüncenin adalet yaklaşımını ve refah devletine bakışını John Rawls'ın "dağıtıcı adalet" kavramında bulabilmek mümkündür. Adalet ilkelerini bir "ilk durum"dan hareketle geliştiren Rawls (1985), ilk durumdaki insanların rasyonel hareket etmekle birlikte bilgisiz oldukları varsayımın "bilgisizlik örtüsü" kavramı ile açıklar. Rawls (aktaran Altıparmak, 2006, s.33)'a göre adalet için taraflar iki temel kabulle hareket etmelidir. Bunlardan ilki, herkesin en kapsamlı temel özgürlüğe sahip olma hakkı, ikincisi de ekonomik ve sosyal eşitliklerin ancak böyle bir dağılımın herkesin yararına olmasıyla hak edileceğidir. İşte bu ilkeler eşit temel özgürlükler ve adil fırsat eşitliğidir.

2. Dünya Savaşı'ndan itibaren başarılı bir uygulama alanı bulan sosyal liberalizmin, 1970'lerde yaşanan krizleri açıklamaktaki yetersizliği "NeoLiberalizm" olarak adlandırılan yeni bir liberal sürecin başlangıcını oluşturmuştur. Küreselleşme etkilerinin hâkim olduğu bu yeni dönem; liberal gelenekteki "sosyal liberalizm" ve "refah devleti" anlayışından uzaklaşılmasına rağmen, liberal tezlerin yeniden canlandığı ayrıca serbest piyasanın işletildiği ve toplumdan bireye yönelişin olduğu bir dönemdir. Bu yeni dönemde devletin üstlendiği görevler eğitim ve sağlık gibi temel alanları da içerecek şekilde genişlemiştir (Erdoğan, 1998, s.14-15).

Neo-liberaller, devletin ne kadar sinırlandırılacağından piyasa-devlet ilişkilerine, sosyal adaletten bireylerin seçim özgürlüklerine kadar birçok alanda konuya yaklaşımları açısından sosyal liberallerden farklılaşmaktadırlar. Neo-liberalizm, liberalizmin bireylerin seçme özgürlükleri ile serbest piyasa ve sınırlı hükümet gibi temel esaslarını kabul ederken; sosyal liberalizmin, liberalizmin özünden koptuğu iddiasını taşımaktadır. Neo-liberaller refah devletinin esasen devletin sınırlarını sürekli genişlettiğini ve bu işlerin piyasaya devrinin gerekli olduğunu düşünürler (Sallan Gül, 2006, s.37-38).

"Geleneksel Muhafazakâr" düşünce de liberal düşüncenin bireycilik ve doğal hukuk anlayışlarına tepki olarak, bireyi toplum içinde algılamayı esas alan düşünce sistemidir. Bu tepkinin temelinde, geleneksel kurumların, uygulamaların ve inançların savunulması yatmaktadır. Düzenin korunması ve sürekliliğin sağlanması düşüncesini esas alan muhafazakârlar, devrimci nitelik taşıyan değişimlerin anarşi ve terörizmi beraberinde getireceğini savunmaktadırlar (Sallan Gül, 2006, s.73-74). 
Geleneksel muhafazakâr düşünce de zaman içerisinde liberal düşünce gibi önemli değişimlere uğramıştır. "Yeni Muhafazakâr" düşünceye göre muhafazakârlık değişime karşı olmak ya da her ne surette olursa olsun yenilik karşıtı olmak değildir. Muhafazakârlar, toplumsal düzeni alt üst eden, geleneksel kurum, sınıf ve meslek yapılarını ortadan kaldıracak şiddette yaşanan değişim üzerinde odaklanarak toplumsal dokuyu ve anlamı zedelemeyecek tedrici bir değişimi savunmaktadırlar (Duman, 2017, s.808). Bu nedenle değişimin ölçülü ve yavaş olmasını istemekte ve değişimin olumsuz etkilerini önlemeye yönelik politikalar geliştirmeye özen göstermektedirler. Aile ve dinin toplumsal yaşam içerisinde taşıdığı önem, muhafazakâr politikaların belirlenmesinde oldukça etkilidir. Öyle ki sosyal politikanın düzenlenmesinde ailenin "koruyucu" ve dinin "bütünleştirici" özelliği kendisini göstermektedir. Toplumda gereksinim içinde olan kişi ya da gruplara yardım edilmesi, toplumsal istikrarın sağlanması düzenin devamı açısından önem taşımaktadır. Ancak bu yardımseverlik anlayışı, devletin müdahale sorumluluğunu içermemektedir. $\mathrm{Bu}$ yardımseverlik aile, yerel ve dinsel topluluklar ve gönüllü yardım kuruluşları tarafından yerine getirilecektir (Sallan Gül, 2006, s.77).

Modern toplum yaşantısı ile uyumlaşma çabası içinde olan muhafazakârlık anlayışı, yeni süreçte bazı geleneksel formlar üzerindeki vurgusunu hafifletmiş ve bazı modern kurumları yeniden biçimlendirmek suretiyle öğretisine dâhil etmiştir (Erdoğan, 1998, s.62-63). Yeni muhafazakâr düşünce, bir yandan liberalizmdeki serbest piyasa ve kapitalizmin ana kurumlar1nı benimserken, sosyo-kültürel konularda ılımlı bir bakış açısını da talep etmektedir. Sosyal sorunların çözümünde geleneksel aile ve din kurumlar1nın koruma ve yardımlaşma fonksiyonlarının kullanılmasını politikalarına eklemlemektedirler (Sallan Gül, 2006, s.83).

\section{Yoksulluk Kavramına Genel Bir Bakış}

\section{Yoksulluk Üzerine}

Yoksulluk karmaşık, değişken, çok boyutlu, ülkeden ülkeye, dönemden döneme ve zaman içinde kuşaktan kuşağa refah düzeyindeki gelişmelere bağlı olarak farklılık gösteren bir olgudur. 21. yüzyılın en önemli sorunu haline gelen yoksulluk, ekonomik ve sosyal bir olgu olarak da sosyal politika alanının ilgi konusu haline gelmiştir. Yoksulluk ile ilgili literatürde farklı 
tanımlamalar mevcuttur. Bu tanım farklılaşmasının nedenleri her ülkenin kendine özgü kıstaslar, bakış açıları ve değer sistemlerine göre yoksulluğu tespit etmelerine bağlanmaktadır. Örneğin Jargowsky ve Bane (1990, s.1617) sürekli yoksulluk, çevresel-mekânsal yoksulluk ve alt sınıf yoksulluğu şeklinde 3 (üç) farklı grup altında bir yoksulluk tanımlaması yaparlarken; DiNitto (1991, s.48-64) daha ayrıntılı bir sinıflandırma yaparak yoksunluk olarak yoksulluk, eşitsizlik olarak yoksulluk, kültürel yoksulluk ya da yoksulluk kültürü, sömürü olarak yoksulluk ve yapısal yoksulluk olmak üzere 5 (beş) tür yoksulluktan söz etmektedir.

Yoksul ve yoksulluk kavramlarını tanımlarken sınırın nasıl çizileceği konusu son derece önemlidir. Bu nedenle yoksullukla ilgili birtakım kavramlar bağlamında yoksulluğun tanım ve türlerini aşağıdaki şekilde tablolaştırmak mümkündür (Erdem, 2003, s.22-23):

Tablo 1. Yoksulluk Tanım ve Türleri

\begin{tabular}{|c|c|c|}
\hline Tanımlar & Kullanan & Tanımı \\
\hline Yoksulluk & (Genel) & $\begin{array}{l}\text { Gelir eksikliği ve azlığı, sosyal mahrumiyet } \\
\text { duygusunun gelişimi. }\end{array}$ \\
\hline Mutlak Yoksulluk & (Genel) & Asgari gelir ve harcama düzeyi. \\
\hline Göreli Yoksulluk & (Genel) & Asgari yaşam düzeyine sahip olma. \\
\hline YoksullukSınırı & Charles Booth & $\begin{array}{l}\text { Ailenin geçim ihtiyaçlarına olanak tanımayan } \\
\text { bir düzeyin altı. }\end{array}$ \\
\hline Birincil Yoksulluk & Joseph Rowntree & $\begin{array}{l}\text { Ailelerin toplam kazançlarının, fiziksel } \\
\text { yeterliliği sürdürmek için yetersiz olması. }\end{array}$ \\
\hline İkincil Yoksulluk & Joseph Rowntree & $\begin{array}{l}\text { Ailelerin kazandığı paranın fiziksel yeterliliği devam ettirmede } \\
\text { yeterli olup, diğer harcamalar için yetersiz olması. }\end{array}$ \\
\hline SubjektifYoksulluk & Jan Drewnowski & Tatminkâr bir gelire sahip olamamak. \\
\hline Gelir Yoksulluğu & Jan Drewnowski & $\begin{array}{l}\text { Asgari yaşam standartlarının gerektirdiği yeterli miktarda gelir } \\
\text { elde edememesi durumu. }\end{array}$ \\
\hline Yoksulluk & Dünya Bankası & $\begin{array}{l}\text { Asgari yaşam standartlarına } \\
\text { ulaşamamak. }\end{array}$ \\
\hline Ultra Yoksulluk & $\begin{array}{l}\text { FAO } \\
\text { (Birleşmiş Milletler Gıda } \\
\text { ve Tarım Teşkilatı) } \\
\end{array}$ & $\begin{array}{l}\text { Gelirin tamamının harcandığı halde mutlak yoksulluk kriterine } \\
\text { esas alınan \%80'inin karşılanabilmesi. }\end{array}$ \\
\hline Kronik Yoksulluk & $\begin{array}{l}\text { WHO (Birleşmiş Milletler } \\
\text { Dünya Sağlık Teşkilatı) }\end{array}$ & $\begin{array}{l}\text { Ultra yoksulluk durumunun beş yıldan daha fazla sürmesi } \\
\text { halinde durumlarının düzelmeyeceğinin kesinlik kazanması. }\end{array}$ \\
\hline Çalışan Yoksulluk & $\begin{array}{l}\text { UNCHS } \\
\text { (Habitat) }\end{array}$ & $\begin{array}{l}\text { Kamu ve özel sektörün alt düzeylerinde ve marjinal sektörde } \\
\text { çalışan eğitim düzeyi düşük ve vasıfsız işgücü. }\end{array}$ \\
\hline Kent Yoksulları & $\begin{array}{l}\text { UNCHS } \\
\text { (Habitat) }\end{array}$ & $\begin{array}{l}\text { Kent özelinde yaşanan konut sorunlarını ve sosyal dışlanmayı } \\
\text { vurgulamak. }\end{array}$ \\
\hline Barınma Yoksulluğu & UNCHS (Habitat) & Ülke genelinde yaşanan konut sorunlarını vurgulamak. \\
\hline İnsani Yoksulluk & $\begin{array}{l}\text { UNDP } \\
\text { (Birleşmiş Miletler } \\
\text { Kalkınma Programı) }\end{array}$ & $\begin{array}{l}\text { Belli kriterler esasında bir ülke vatandaşlarınıninsanca yaşama } \\
\text { imkânlarının bulunup bulunmadığını tespit etme. Uluslararası } \\
\text { kyyaslama yapabilmek için ülkeleri, yaşam süresi, bilgi ve onurlu } \\
\text { bir yaşam standardını ölçütlerine göre değerlendirmek. }\end{array}$ \\
\hline
\end{tabular}

Kaynak: (Erdem, 2003, s.22-23)'ten yararlanılarak hazırlanmıştır. 
Yoksulluk düzeyi bakımından farklı ülkeler arasında kimlerin yoksul olarak isimlendirileceğinin net bir şekilde tanımlanması gerekmektedir. $\mathrm{Bu}$ tanımlamayı yapabilmek için yoksulluk kavramının farklı yaklaşımlar açısından nasıl incelendiği kavramın analizi açısından önem taşımaktadır.

\section{Mutlak Yoksulluk - Göreli Yoksulluk}

Yoksullukla ilgili çalışmalar yürüten ve yoksullukla mücadelede önemli uluslararası kuruluşlardan biri olan Dünya Bankası için mutlak yoksulluk önemli bir göstergedir (Devlet Planlama Teşkilatı [DPT], 2001, s.103). Yoksulluğun bütün dünyada ölçümlenebilmesi, nesnel kriterlere dayalı bir ölçüm yöntemini gerekli kılmış ve sonuçta Dünya Bankası tarafından "mutlak yoksulluk" kavramı geliştirilmiş ve bu tanım, yoksulluk tanımlamasında uzun yıllar kullanılmıştır. Mutlak yoksulluk birey ya da hanehalkının yaşamını sürdürebilecek ve ihtiyaçlarını giderebilecekleri asgari gelir olarak tanımlanir (Sallan Gül, 2002, s.108).

Mutlak yoksulluk yaklaşımına ilişkin olarak ülkelere göre değişen sorunlar vardır. Bunlar; uygun yoksulluk kıstasının seçimi, verilerin toplanması, anketlerin düzenlenmesi ve ölçüm dönemi, ölçüm yeri, ölçüm birimi, yoksulluk çizgisinin güncelleştirilmesi, eşdeğerlik ölçeği gibi teknik sorunlardır. $\mathrm{Bu}$ sebeplerden dolayı mutlak yoksulluk kavramı çeşitli açılardan birçok eleştiriye maruz kalmıştır. Şenses (2006)'e göre, mutlak yoksulluk kavramına yöneltilen eleştirilerin en önemlisi öznel nitelikler taşımasıdır. Ayrıca mutlak yoksulluk çizgisi yaklaşımına yönelik "yoksul kitle içindeki çeşitliliği yansıtmadığı"; "yoksulluğun mutlak değil göreli bir kavram olduğu"; "mutlak yoksulluk yaklaşımının yoksulların görüşlerini dikkate almadığı"; "mutlak yoksulluk kıstaslarının yeterli birer refah göstergesi olmadığı" şeklinde eleştiriler de ileri sürülmektedir (Şenses, 2006, s.80-96).

Yapılan bu eleştiriler yoksullukla ilgili yeni yaklaşımların ortaya çıkmasına neden olmuştur. Göreli yoksulluk bu eleştirilerin sonucunda ortaya çıkan bir kavramlardan biridir. Diğer bireylere göre ortalamanın altında bir gelire sahip olma durumu olarak tanımlanan göreli yoksulluk da temel ihtiyaçlar yine önemlidir. Tüketim ve gelir durumuna göre belirlenen ortalama refah durumu ön plana çıar. Gelir ve tüketim skalası son dönemlerde gelişmiş toplumlarda yerlerini toplam gelire bırakmaktadır. Toplam geliri belli bir miktarın -ki bu miktarm altı yoksulluk çizgisi olarak belirtilmektedir- altında 
olan birey veya hanehalkı yoksul kabul edilir (Türk Sanayicileri ve İşadamları Derneği [TÜSİAD], 2000, s.97-98; Sallan Gül, 2002, s.109). Mutlak ve göreli yoksulluk arasındaki temel fark, mutlak yoksullukta, asgari minimum ihtiyaçlar üzerinden bu çizgi belirlenirken, göreli yoksullukta ortalama gelir düzeyi temel alınmaktadır (TÜSİAD, 2000, s.96).

Asgari ihtiyaçların belirlenmesi ve yaşam standardının ne olduğu/olması gerektiği konusunda farklı anlayış, ölçüt ve uygulamalar bulunmaktadır.

\section{Objektif Yoksulluk-Sübjektif Yoksulluk}

Objektif yoksulluk yaklaşımı, yoksulluğu ortaya çıkaran nedenlerin önceden belirlenmiş olmasına dayanır. Sübjektif yaklaşımda ise bireylerin tercihleri, kişi ve hanehalkı değerlendirmeleri esastır. Bireylerin kendileri için en iyisini bilecekleri savlanır. Tükettikleri yiyeceklerin miktarı ve türleri konusunda kendileri karar verici olurlar. Ancak Aktan (2002, s.43)'a göre bu durumun geçerliği tartışmalıdır. Zira bireyler her zaman doğru kararlar veremeyebilirler. $\mathrm{Bu}$ nedenle genel eğilim objektif yaklaşımın benimsenmesi yönündedir.

\section{Sosyal Dışlanma ve Yoksulluk}

1960'lı 1970'li yıllar için yoksulluk kavramı, yaşanmakta olan toplumsal olguları kavramakta yeterli olurken, 1990'ların dünyasında yeni bir olgunun gelişmesi karşısında yeterliliğini kaybetmiştir. Bu yeni olgu tanımlarken "dışlanma" kavramını kullanılmaya başlanmıştır. Küreselleşen ve teknolojik olarak yeniden yapılanan dünya ekonomisi içinde uyum sağlayamayan gruplar ve kişiler daha kolay dışlanabilmektedir (Tekeli, 2000, s.139). Sosyal dışlanma ve "yapabilirlik yoksunluğu" arasında bağlantı kuran Amartya Sen (2005, s.3-5) yoksulluğun geniş görüş açısı içinde yer aldığını belirtmekte ve sosyal dişlanmanın yapabilirlik yoksunluğunu biraz daha genişleten bir kavram olduğunu vurgulamaktadır. Yapabilirlik yoksunluğu sonucu toplumsal yaşama katılamama sosyal dışlanma sonucunu doğurabilmektedir.

Sosyal dışlanma; yoksulluk, asgari eğitim ve yeteneklerden yararlanamama ve ayrımcılık nedeniyle kişilerin toplumdan itilmeleri ve katılım kanallarının onlara kapalı olması olarak değerlendirilmektedir (Adaman ve Keyder, 2005, s.iii). Sosyal dışlanmanın ekonomik, sosyolojik ve psikolojik 
olmak üzere üç boyutu vardır. Ekonomik boyutunda yer alan gelir ve tüketim durumu dışlanmanın niteliğini ve içeriğini de belirler. Dışlanmanın toplumun hangi gelir ve tüketim seviyesinde gerçekleşeceği da sosyal dışlanmanın sosyolojik boyutudur. Sosyal dışlanma şiddetine bağlı olarak, bireyin kendisini yetersiz, değersiz ve suçlu görmesi durumu ise sosyal dışlanmanın sosyolojik boyutu temelinde gerçekleşen psikolojik boyutudur (Aldemir ve Özpınar, 2004, s.5-6).

Bauman (1999, s.124-127)'a göre dişlananlar yalnızca yoksullar değildir. Ne var ki yoksullar dışlanmayı en keskin ve şiddetli şekilde yaşayanlardır. Bauman yoksulların düzen için bir tehdit ve engel olduğunu ayrıca normu hiçe saydıklarını belirtir ve dışlananları iki türde kategorize eder: Düzeni bozanlar ve norma uygun olmayanlar. Bu bağlamda Bauman (1999, s.10), tüketim toplumunda seri imalatın artık kitlesel emek gücüne ihtiyaç duymadığ1 ve bir zamanların "yedek sanayi deposu" olan yoksulların "defolu tüketicilere" dönüştürüldüğü düşüncesindedir.

\section{Yoksulluk Kültürü}

1950 ve 1960'larda Amerika' da geliştirilen ancak 1980'lerden sonra yeniden güncel nitelik kazanan yoksulluk kültürü yaklaşımı, modernleşme kuramları bağlamında yoksulluğu, modernleşememenin ve kentle bütünleşememenin bir sonucu olarak ortaya çıkan alt kültürde gelişen anomik bir olgu ve sosyal bir sorun olarak görür (Sallan Gül, Gül ve Ergun, 2003).

Lewis, yoksulluk kültürü kavramını ve kavramla anlatılmak istenenleri genel olarak "Beş Aile: Yoksulluk Kültüründeki Meksikalılar Üzerine Alan Çalı̧ması", "İste Hayat" ve "Sanchez'in Çocukları" adlı eserlerinde ele almıştır. Lewis (1971, s.XXIII)'e göre yoksulluk kültürü; yoksulları pozitif etkiler. Onları kendi yoksullukları içinde yaşar kılar bu etki. Lewis'de yoksulluk patolojik bir olgu, suçla birlikte ele alınan toplumsal bir sorundur. Başarı standartlarına ve çalışma ahlakına düşük bağlılık, siyasal katılım süreçlerinde yer almama, örgütlü hareket edememe, kalabalık yerlerde yaşama, kavgaya ve şiddete yatkınlık, cinsel iradesizlik, alkol ve uyuşturucu düşkünlüğü gibi değişkenler yoksulluk kültürünün temel özellikleri olarak gösterilmektedir. Lewis' in (aktaran Gül ve Sallan Gül, 2008, s.67-69) yoksulluk kültürü yaklaşımının genel felsefesi 3 (üç) tez halinde şu şekilde özetlenmektedir: 

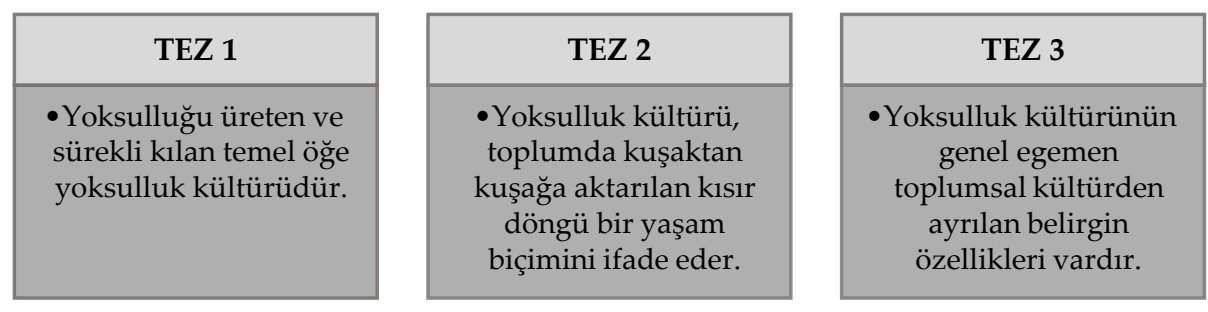

Bireye, piyasaya ve kapitalizme yapılan vurgu ve devlet için yoksullara yönelik tutumlar konusundaki ufak tefek farklılıklar dışında, neo-liberal yaklaşım ile yeni muhafazakâr yaklaşımın yoksullara ve yoksulluğa bakışta benzer tezlere sahip olduğunu ifade eden Gül ve Sallan Gül (2008) bu bağlamda, yeni muhafazakârların yoksulluk kültürü tezlerini sosyal devlete bir saldırı aracı olarak kullandıkların; neo-liberallerin ise yoksulluğu piyasanın işleyiş dinamiklerinden kaynaklanan geçici bir sorun olarak görüp, yoksulları ahlaki yönden zayıf, üretken olmayan, tembel bir grup olarak değerlendirdiklerini vurgulamaktadırlar.

\section{Yoksulluk Tartışmalanı ve Kent Yoksulluğu}

Yoksulluğun artışındaki süreklilik ve önlem alınmadığı müddetçe bu artışın daha da şiddetleneceği konusunda görüş birliği bulunmaktadır. Yaşanan küreselleşme süreciyle birlikte, öngörülenin aksine gelir dağılımındaki dengesizlik daha da belirginleşmiş; makro-ekonomik istikrar ve yapısal uyum programları milyonlarca insanın yoksullaşmasına yol açmıştır. Dünyada gelişen teknolojiyle beraber artan üretimin yanı sıra, yeterince tüketemeyen insan katlanılması güç yoksulluk koşulları içinde yaşamaktadır. Yaşanan yoksulluğun çoğu az gelişmiş ülkelerde ve özellikle Asya, Afrika, Latin Amerika, Pasifik Bölgesi ve Karayipler'de yer alan düşük gelirli ülkelerde görülmektedir (Chossudovsky, 1999, s.37; Şenses, 2006, s.20-21).

Yoksulluk temelde az gelişmiş ülkelerde yaşanan bir sorun olsa da gelişmiş ülke toplumlarında da oldukça önemli bir sorun alanı olarak karşımıza çıkmaktadır. Özelikle kentsel alanlarda yaşayan ve "marjinaller", "dışlanmışlar" veya "underclass (sınıf-altı)" diye tabir edilen yoksul sınıflar son zamanlarda giderek dikkat çekmeye başlamıştır (Buğra ve Keyder, 2003; Aldemir ve Özpınar, 2004). 1970'li yıllarda ithal ikameci kalkınma politikalarının iflası ve sistemin bir bütün olarak krize girmesiyle birlikte, özellikle 
1980'liyıllardan itibaren, kapitalist sistem yeniden inşa edilmiştir. Sosyal devlet anlayışının da giderek geride kaldığı bu yeni liberal dönemde artık yeni bir toplum ve birey tanımı yapılmış, bireyler piyasa içinde alıcı ve satıcı durumuna gelmiştir (Gül ve Sallan Gül, 2007). Şenses (2006)'e göre yeni liberal ekonomi politikaları, gelişmiş ülkelerle gelişmekte olan ülkeler arasındaki gelir dağılımı uçurumunu giderek arttırdığı gibi, ülkelerin içindeki farklı kesimler arasında gelir farklılıklarının yaşanmasına yol açmıştır. Dünyada yaşanan büyük dönüşüm yoksulluk açısından özellikle iki yönden dikkati çekmektedir. Sermayenin akışkanlığının olağanüstü derecede hızlanmasıyla birlikte işverenler ucuz işçi çalıştırabilecekleri ülke ve sektörlere yönelmektedir. Sermayenin bu akışkanlığı sayesinde işverenler, sendikasız, sigortasız ve ucuz işçi nerede ise yatırımlarını oralara yönlendirmiştir. Bunun sonucunda bir taraf hep zenginleşirken diğer taraf giderek fakirleşmiştir. Yani küresel kapitalizm fakirleşmeyi durdurmamış aksine yoksulluğun daha da artmasına neden olmuştur.

Yoksulluğun küreselleşme süreci ile birlikte geldiği bu noktada, yeni bir kavram olan "dışlanmışlık" kavramı soruna yeni boyutlar kazandırmıştır. Dünya Bankası'nın 2001 yılında yayınladığı "Yoksulluğa Saldırmak" başlıklı Dünya Kalkınma Raporu'nda (World Development Report, 2001, s.15) “dışlanmışlık" şu sözlerle ifade edilmektedir:

"Yoksulluk refahta yoksunluk şeklinde ifade edilir. Ama tam olarak yoksulluk ne demektir? ...Yoksul olmak; aç olmak, barımma ve giyecek ihtiyacını karşılayamamak, hasta olmak ama tedavi olamamak, okuma yazma bilmemek ve okula gidememek demektir. Ama yoksul insanlar için, yoksulluk içinde yaşamak bundan fazlasıdır. Yoksul insanlar özellikle kendi kontrolleri dışında gelişen olaylara karşı savunmasizdırlar. Genellikle devlet kurumları ve toplum tarafindan kötü muamele görürler ve hatta bu kurumlarda söz sahibi olmaktan ve iktidardan dişlanirlar."

1980'lerden itibaren gündeme gelen "yoksulluk" olgusunun geçmişteki yoksulluk formlarından farklı bir nitelik taşıdığını belirten Özbudun (2002)'a göre "yeni yoksulluk" olgusunu 'toplumsal dişlanma', 'marjinalleş(tiril)me' ve 'sınıf-altı' toplumsal/kültürel yön ve boyutlarıyla ele almak gerekmektedir. İster dişlanmışlık, ister marjinallik isterse underclass olarak adlandırılsın yeni yoksulluğu tanımlayan ortak özellikler ile ilgili Özbudun (2002, s.58-60) şu şekilde saptamalarda bulunmaktadır:

"Yeni yoksulluk geri dönüşsüz ilan edilen neo-liberal politikalarn bir sonucu olduğu ölçüde geri dönüşsüzdür. Neo-liberalizmin ücretleri düşürücü, istihdamı ve 
kamusal alamı daraltıcı baskısı, dünya nüfusunun büyüyen bir kesimini işsizliğe ya da güvencesiz, marjinal, "esnek" işlerde sefalet ücretleriyle çalışmaya mahkum kılmaktadır. Sosyal bütçelerde yapılan kısıtlamalar sonucu eğitim hizmetleri yoksullar için erişilemezleşirken, erişilebilir durumdaki eğitim kalitesi de giderek düşmektedir. Bu durum yoksulluğu kuşaklar boyu içinden çıklmaz bir "kısır döngü" ye dönüştürmektedir. ...Bu yeni yoksulluk yalnızca temel gereksinimlerini karşılayamamakla değil, iktisadi, siyasi, toplumsal ve kültürel dışlanmışlıkla da karakterize olmaktadır. Gerek gelişmiş gerekse az gelişmiş ülkelerde yoksulluk "etnikleşmekte", "gençleşmekte" ve "kadınlaşmaktadır". Dünya yoksulluğu giderek belirli toplumsal grupları vuran bir nitelik kazanmaktadır."

Yoksulluk açısından ortaya çıkan bu resim karşısında yoksulluk üzerine genel bir ilginin oluştuğu görülmektedir. Bu ilginin 1970 sonrası ulusal ve uluslararası camiada anlam bulduğu, gelecek için şimdiden önemler alınması gerektiği farklı platformlarda sürekli vurgulanmıştır. Örneğin, 1995 yılında Pekin'de toplanan BM 4. Kadın Konferansı'nda kadınların karşı karşıya kaldıkları önemli sorunlar açısından yoksulluk ele alınmıştır. 2001 yılında Davos'ta toplanan Dünya Ekonomik Forumu'nun ana temasını da yoksulluk oluşturmuştur. Ayrıca, BM 1996 yılını Yoksullukla Mücadele Yılı, 1997-2006 dönemini de Yoksullukla Mücadele On Yılı ilan etmiştir. 2000 yılında yapılan Binyıl (Milenyum) Zirvesi'nde de mutlak yoksulluk içinde yaşayan insan sayısının 2015 yılına kadar yarıya indirilmesi yönünde ilke kararı alınmıştır (Şenses, 2006, s.22-25).

Dünya Bankası'nın yoksulluk konusuna ilgisi özellikle dikkat çekicidir. Dünya Bankasının yoksulluğa yaklaşımı birbirinden farklı stratejilerin söz konusu olduğu 3 (üç) kırılma noktasından oluşmaktadır. Şenses (2006, s.39) bu kırılma noktalarını 1970'li yıllar, 1980'li yıllar ve 1990'lı yıllar şeklinde tarihlemektedir. 1970'li yılların başlarında Dünya Bankası yoksulların beslenme, barınma, sağlik ve eğitim gibi temel gereksinimlerinin karşılanmasını hedefleyen "Temel İhtiyaçlar Stratejisi"ni; yatırımların yoksul gruplara yönlendirilmesini ve böylelikle büyüme ile birlikte yoksulların gelirlerinin arttırılmasını amaçlayan "Büyümeyle Birlikte Yeniden Dağıtım Stratejisi"ni ön plana çıkarırken, kırsal yoksulluk ve 1970'lerin sonlarına doğru da kentsel yoksulluk Dünya Bankası'nın gündemine girmiştir.

Dünya Bankası 1980'li yılların başlarından itibaren bu tür yaklaşımların yerine yapısal uyum programları aracılığıla kısa dönem istikrar politikalarını tercih edip IMF ile birlikte hareket ederek neo-liberal politikaların yay- 
gınlaşmasında önemli rol üstlenmiştir. 1980'li yıllar Dünya Bankası açısından yoksulluğun her ülkenin iç sorunu olarak görüldüğü ve yaklaşık on yıl süreyle gündemden büyük ölçüde çıkarıldığı "kaybolan on yıl" şeklinde nitelenen yıllardır. Dünya Bankası'nın yoksulluğa bakış açısındaki temel değişiklik ise 1990 Dünya Kalkınma Raporu ile gerçekleşmiştir. Raporda yoksulluk bir ekonomik gelişme ölçütü olarak ele alınırken, insanlık için çözüme kavuşturulması gereken en önemli sorunlardan biri olarak değerlendirilmiştir (Şenses, 2006, s.40-41).

Kentsel yoksulluk sadece gelir azlığını ve kentsel hizmetlerden yeterince yararlanmamayı kapsamamaktadır. Aynı zamanda, eğitim, sağlık, güvenlik gibi hizmetlerden daha az faydalanmayı, varoşlarda yaşamayı, kentsel şiddete daha açık olmayı içinde barındıran bir ifadedir (Çolakoğlu, 2003, s.466). Kentsel yoksulluk, ekonomik ve sosyolojik yaklaşımlar ile kent ve bölgesinin belirli kaynaklardan yoksun oluşunun yanı sıra, bir ekonomik mekanizma ya da bir toplumsal gerçeklik anlamında kentin göreli dengesizliği, düzensizliği ve bozulmuş işlevselliği; ayrıca toplumsal etkinlik, yetkinlik ve organizasyonlar açısından da bir yetersizlik anlamına gelmektedir (Bilsel, Polat, Çalışır ve Hovardaoğlu, 2002, s.193).

Günümüzde yoksulluk konusundaki tartışmaların odak noktasında, ABD'de 'sınıf-altı', Fransa'da 'dışlananlar' ve Latin Amerika'da da 'marjinaller' şeklinde nitelenen yeni kent yoksulları yer almaktadır. Farklı coğrafyalardan kaynaklanan bu kavramlar farklı sosyal politika ve teori önerilerini içermektedir (Buğra ve Keyder, 2003, s.20). Kırsal yoksulluğun adresi Asya iken kentsel yoksulluğun adresi ilk olarak yüksek kentleşme oranı ile Latin Amerika'dır (Şenses, 2006, s.116).

Sınıf-altı kavramı kelimenin kurgusunun çağrıştırdığı biçimde alt sınıfa mensup bir kitleyi değil de taşıdığı davranışsal karakterden ötürü bilinen sosyolojik ve iktisadi sinıflardan birine dâhil olmayan, toplumun geneliyle uyuşan verili bir etik normu olmayan, çoğu kez işsiz, yardım bağımlısı ve yetersiz eğitiminden veya buna eşlik eden etnik dezavantajından dolayı dikey ilerleme imkânı olmayan bir kesimi anlatmaktadır (Bıçkı, 2005, s.112). Fransa ve $A B$ ülkelerinde kullanılan sosyal dışlanma kavramı, sınıf-altı kavramına yaklaşmaktadır. Yine katılım yokluğu ve temel hizmetlere uzaklık dikkat çekmektedir (Adaman ve Keyder, 2005, s.6). Daha çok Latin Amerika kaynaklı "marjinallik" (kenardanlık) ise, özünde sisteme entegre olamamışlığı belirten bir kavramdır (Buğra ve Keyder, 2003, s.20). 1970'lerin Latin 
Amerika tartışmalarına damgasını vuran "merkez-çevre" dikotomisine dayanan ve genellikle kapitalist sistemle bütünleşememiş, kırsal kökenli kent yoksullarını işaret eder. Latin Amerika'da ve Güney ülkelerinin çoğunda kent yoksulları yakın bir kırsal geçmişe dayanan etnik gruplardır. Kentsel yoksullukları ve dışlanmışlıkları maruz kaldıkları ayrımcılık biçimleriyle iç içe örülmektedir (Özbudun, 2002, s.56).

Yeni kentsel yoksulluğun, genel yoksulluktan farklı tarafı, küreselleşme ile birlikte öngörülemeyen ve önceleri yoksul olarak nitelenemeyecek kesimlerin ortaya çıkması ve kendilerine özgü bölgelerde yaşamalarıdır. Toplumsal ve mekânsal açıdan "yersiz" diye tabir edilen bu insanlar gökdelen altlarında, metro banliyölerinde, karton kutular üzerinde yaşam sürdürmektedirler. $\mathrm{Bu}$ şekilde ifade edilen yoksul kesimlere daha çok ABD metropolleri gibi gelişmiş ülkelerin metropollerinde ve "dünya kenti" olarak nitelenen Batılı ülkelerinin metropollerinde rastlanmaktadır (Bıçkı, 2005, s.106). Türkiye'de ise 1950'lerden itibaren ortaya çıkan göç olgusu ile biçimlenen kent yoksulluğu ile diğer büyük metropollerdeki sinıf-alt diye tabir edilen yoksul kesimlerle benzerlik kurmak mümkün görünmemektedir. Kendine özgü yapısıyla göç edenler enformel ağlar üzerinden kenti deneyimlemişlerdir. Işı ve Pınarcıoğlu (2018, s.97)'na göre Türkiye kentlerinde hemen her grup, ama özellikle kent yoksulları, kapsamı ve işleyiş mekanizmaları bir yerden diğerine önemli ölçüde farklılıklar gösteren ilişki ağları içinde var kalmanın yollarını aramışlar ve bu korunaklı ilişkiler sistemi, zaman içerisinde büyük çaplı değişiklikler gösterse de Türkiye kentleşmesinin ilk aşamalarından bu yana varlığını sürdürmeye devam etmiştir.

\section{Kent Yoksulluğundan Yeni Kent Yoksulluğuna}

Küreselleşme akımı yapısal uyum ve istikrar programları çerçevesinde neredeyse tüm dünya ülkelerinde gündeme getirilip uygulamaya sokulan esnekleşme ve kamu kuruluşlarının özelleştirilmesi ve hatta ulusaşırı şirketlerle ulusal şirketlerin "evlenme" yoluyla birleşmeleri neticesinde yabanc1laştırılması politikaları pek çok ülkede ulusal istihdam yapılarını çözmüş ve birçok işçinin işten çıkarılmasına, muazzam sayıda düşük ve orta gelirli insanın ve dolayısıyla ailenin yoksullaşmasına sebep olmuştur. İstihdam yapılarının çözüldüğü bu durum "yeni yoksulluk" olarak tanımlanmaktadır (Bostanoğlu, 2002, s.341). 1980'lerden itibaren benimsenen neo-liberal 
ekonomi politikalarına bağlı olarak yaşanan yapısal dönüşüm süreci ile birlikte küresel kapitalizm sürecinin kentlere etkisi tartışılmaya başlanmıştır. Tartışmaların odağ 1 genel olarak söz konusu süreçlerin farklı sınıf ve kesimler üzerindeki etkileri iken kent yoksulları özel bir ilgiyle ele alınmıştır (Özbek Sönmez, 2002a, s.460; 2002b, s.247). Özellikle söz konusu yıllarda kentler üzerinde etkisi giderek artan çağdaş kentsel gelişme dinamikleri, kent yoksulları üzerinde ekonomik ve psikolojik baskı yaratmıştır. Küresel/kapitalist düzenin bir gereği olarak ortaya çıkan küresel işgücü piyasasının rekabetçi koşulları bir yandan gelir düzeyinin ve sosyal güvenlik haklarının azalmasına neden olurken diğer yandan yaşam kalitesini olumsuz etkileyen çalışma koşullarının ortaya çıkmasına neden olmuştur (Ünsal, 2002, s.60).

1996 yılında Brezilya'nın Recife kentinde düzenlenen "Kentsel Yoksulluk: Bir Dünya Meydan Okuması" başlıklı toplantıda kentsel yoksulluğun önemli yönleri, nedenleri ve sonuçları ile ihtiyaç duyulan politikalar hakkında bir diyalog ve tartışma platformu oluşturulmuştur. Kentsel yoksulluğa karşı mücadelede kilit aktör olarak yerel yönetimlere odaklanan konferansın sonuç bildirgesinde küreselleşmenin yarattığ fırsatların yanında kent yoksulları için ciddi riskleri içinde barındırdığı, ekonomik yeniden yapılanmanın, finansal pazarların küreselleşmesinin ve yapısal uyumun bütüncül etkileri düşünüldüğünde, bunların düşük istihdamlı ve düşük temsiliyetli sınıfları daha da yoksullaştırma eğiliminde oldukları ve orta sınıfların da bu risk grubunda yer aldığına dikkat çekilmiştir (Recife Declaration, 1996).

Günümüzde yoksullukla mücadelede piyasa içi çözümler öne çkarken bölgesel yerel ölçekte çözüm arayışları ve politikaları ağırlıklı olarak dile getirilmektedir. Çoğu ülkede, enformel sektör işleri yaygınlaşmakta ve enformel sektör de yoksulluğu giderek arttırmaktadır. Ülkemizde de aynı şekilde gelir ve servet dağılımındaki eşitsizlikler ile birlikte kentsel işgücü piyasasındaki enformelleşmeyle birlikte yoksulluk derinleşmektedir. Kentsel yoksulluk, çoğunlukla kırdan kente göç eden, niteliksiz ve mülksüz olarak kentsel hayata ve çalışma yaşamına giren ancak işgücü piyasasının koşullarından dolayı enformel sektörde istihdam edilen ve gecekondularda yaşayan kişiler ile ailelerini etkileyen bir olgu olarak karşımıza çıkmaktadır (Gül ve Sallan Gül, 2004, s.1-2).

Son dönem kent araştırmalarının ortaya koyduğu en önemli sonuçlardan bir tanesi kentsel yoksulluğun hızla artmasıdır. İnsan hayatının merkezine 
gittikçe daha fazla yerleşen kentler, günümüzde küresel ağlara dâhil olma kaygısıyla birlikte sermaye tarafından çekici yatırım alanları olarak görülmekte, küresel süreçlere eklemlenmeye çalışmakta, bu doğrultuda uygulanan kentsel politikalar ile dizayn edilmekte ve yeniden yapılandırılarak küreselleşme sürecinde cazip kentler haline getirilmeye çalışılmaktadır (Beyazıt, 2019, s.97). "Küresel rekabet ortamında akışkan küresel sermayeyi kendilerine çekme yarışında olan kentler" (Ergun, Gül ve Sallan Gül, 2013, s.61); aynı zamanda geçmişten daha derin bir biçimde hissedilen ve daha fazla görünür olan bir nitelikte ve nicelik olarak da artarak kent yoksullarını bünyesinde barındırmaktadır.

İşte bu nicel artışla birlikte yoksulluğun değişen yüzü Işık ve Pınarcıŏ̆lu (2018) tarafından yeni bir yoksulluk tanımında kendini bulmuştur. 1980 sonrası ortaya çıkan enformel dayanışma ağlarının ve yoksulluğun devredilebilir rolünün üzerinde duran ve Türkiye'nin yoksulluk tipolojisinin ve haritasının kökten değişime sahne olduğunu ifade eden Işık ve Pınarcıoğlu (2008) "nöbetleşe yoksulluk" olarak kavramlaştırdıkları bu yeni yoksulluk olgusu ile Türkiye'deki kentleşme ve göç dinamiğiyle iç içe geçen temel bir stratejiyi tanımlamaktadırlar. Kente bir önceki göç dalgalarıyla gelen kesimlerin yoksullarının kurdukları ağ türü ilişkiler sayesinde kendilerinden bir sonra kente gelen kuşağa yoksullukların devredebilmelerini olanaklı kılan bu devredilebilir yoksulluğa "nöbetleşe yoksulluk" adı verilmektedir. Işık ve Pınarcıoğlu (2018, s.77)'na göre, enformel işgücü piyasasında yer bulan ve kentsel ranta bir şekilde eklemlenen kitleler, kente sonradan göçenlere yoksulluğu aktararak döngüsel bir sarmal oluşturmuşlardır.

"Nöbetleşe Yoksulluk" aynı zamanda kentte birlikte yaşamayı olanaklı kılan yeni yapının da adıdır (Işık ve Pınarcıoğlu, 2018, s.40). Her seferinde arsa ve konut piyasasında kurulan ilişkilere dayanması; çoğu kez iş piyasasında kurulu olan, özellikle hemşehrilik esaslı ilişkilerle eklemlenmesi; bu piyasalarda yaratılan getirilerin sistem içinde yer alanlara eşitsiz dağıtımı ve bu eşitsiz getiriler temelinde yükselen politik ilişkiler nöbetleşe yoksulluk sisteminin temel özellikleri arasında sayılmaktadır (Işık ve Pınarcıŏglu, 2018, s.36).

Yeni kentsel sınıfların ya da tabakaların ortaya çıkması, "yeni kentsel yoksulluk" kavramını da ortaya çıkarmış ve bu yönde yapılan çalışmaların sayısı artmıştır (Erder, 1996; Kaygalak, 2001; Özdek, 2002; Buğra ve Keyder, 2003; Adaman ve Keyder, 2005; Erdoğan, 2007; Işık ve Pınarcıŏlu, 2018). 
Kavram, küreselleşmenin bir başka boyutu olan niteliksiz işgücünün kentlere yığılmasına ve kentlere yönelik göçe dayalı yer değişikliklerine karşılık gelen bir kavram olarak kullanılmaya başlanmıştır. Kentler hızlı ve düzensiz iç ve dış göç hareketi nedeniyle sayıları milyonları bulan bir nüfus kütlesini barındırmak zorunda kalmışlardır. Kentlere yönelen ve aşırı ölçüde nüfus birikime yol açan göç, aynı şekilde işsizliğin artmasına yol açarken, diğer yandan da işsizlikten doğan sosyal sorunların ortaya çımasına ve kentin yerleşim, konut, çevre, altyapı, ulaşım, eğitim, sağlık ve asayiş sorunlarının artmasına neden olmuştur Bu dönemde özellikle kentsel eşitsizliklerden kaynaklanan kentsel gerilimler de arttırmıştır (Beyazıt, 2019, s.90-91).

İlk başlarda gelişmiş ülkelerde kapitalist kentlerin yapısal bir özelliği; azgelişmiş ülkelerde ise düşük sanayileşme ve hızlı kentleşmenin bir sonucu olarak görülen kentsel yoksulluk süreç içerisinde farklı bir nitelik yaşamaya başlamıştır. Yeni kentsel yoksulluk kavramsallaştırmasında kentsel yoksulluk, artık nüfusun küçük bir kısmı açısından durağan bir olgu olarak tartışılan ya da düşük sanayileşme ve hızlı kentleşmeyle bağlantılı bir olgu olarak açılanmaktayken; neo-liberal politikalar sonucunda enformel sektör, taşeronluk gibi istihdam biçimlerinin ekonomideki ağırlıklarının artarak yaygınlaşmasını ve kronik bir hal almasını içeren daha geniş bir kavrama karşlık gelmektedir (Kaygalak, 2001, s.126-127).

Erder (2002, s.37)'e göre, kent yoksullarının yoksullukları gelir yetersizliğinden ziyade, bu grupların kentteki diğer grupların ulaştığı bazı hizmetlere ulaşamamasından kaynaklanmaktadır ve bu nedenle yoksulluk kavramı gelir dışındaki değişkenlerle özellikle yaşama alanlarının kalitesiyle de ilişkilendirilerek yeniden tanımlanmalıdır. Castells (1997, s.27-28) "Kent, Sinff, İktidar" adlı eserinde sınıflı her toplumda görülen toplumsal eşitsizliğin günümüzde ortak tüketim alanlarındaki süreçlerle ilişkilendirilerek tanımlandığını; eşitsizliğin konut koşulları, çalışma saatleri, sağlık, eğitim ve kültürel imkânlar gibi ortak hizmetlere ulaşabilirlik şeklinde tanımlanabilen yeni toplumsal ayrım noktalarıyla anlamlandırıldığını belirtir. Bu bağlamda Giddens (2001, s.97-98) özellikle ekonomik kriz ve sonrası dönemlerde giderek daha çok bireyin işsiz kaldığını, bu yüzden yoksullaştığını ve diğer toplumsal süreçlerden de dışlanarak bu süreçlerin dişında kaldığını vurgular. 


\section{Sonuç Olarak}

Yaşanan küresel süreçte kapitalizm, bugün olduğu gibi gelecekte de bütün insanlığın "kurtarıcısı" olacak sihirli bir düzen olarak sunulur. Kapitalizmin sihiri şuradadır: "Sorunu ben yaratırım ama onu yine ben çözerim. Çözerken de insanlı̆̆a "değer" katarım, kattığım bu değer de bir ilerlemedir." Yoksullukla mücadelede de kapitalizm bu noktadır. Kapitalizmin bu belirleyiciliği, soruna kendi penceresinden bakma alışkanlığı yeni de değildir. Burada önemli olan kapitalizmin yoksulluk üzerinden kendini yeniden ele alıp alamayacağı alırsa bunun nasıl gerçekleşeceğidir. Buğra (2008, s.13), bu açıdan sosyal politikanın hak temelli bir süreçte aynı zamanda kapitalizmi de dönüştürebileceğini ileri sürer.

Yoksulluğun farklı görünümleri mevcuttur ve bu farklılık soruna ilişkin çözüm önerilerini de farklılaştırmaktadır. Tekeli (2000); yoksulluk olgusuna çözüm konusunda dört boyutta farklılaşma gösteren stratejiler önermektedir. Birinci boyut çözümün arandığı düzey ile ilgilidir. Bireysel ya da toplumsal ikilem çerçevesinde bir çözüm seçeneği mevcuttur. İkinci boyut, çözümün nerede aranması gerektiğine ilişkindir. Seçenek olarak da ekonomik bütünleşme/siyasal bütünleşme öne sürülmektedir. Üçüncü boyut, yoksulluğa müdahale eden aktörün temel niteliğiyle ilgilidir. Devlet ve sivil toplum kuruluşları da üçüncü boyutun iki farklı seçeneğidir. Dördüncü boyut ise çözümün nasıl bir örgütlenme ile çözümlenebileceğine ilişkindir. Seçenekler ise yerel/ülkesel şeklinde ortaya konmaktadır.

Yoksulluğun görünürleşmesi beraberinde yoksulluk süreç ve dinamiklerinin belirlenmesini ve bu çerçevede sosyal politikalar geliştirilmesini gerekli kılmaktadır. Bu stratejiler temelinde bir değerlendirme yapmak gerekirse, yoksulların temel ihtiyaçlarının giderilmesinde geçici yardımların dağıtılmasından ziyade insan kaynaklarının geliştirilmesine yönelik uygulamalara önem verilmesi gerekliliği sorunların çözümü açısından elzemdir. Giddens'ın (2001) "Mümkün olan her yerde insan sermayesine yatırım yapılsm" yaklaşımı bağlamında, insan sermayesini geliştirmeye yönelik sosyal politikalar yoksulluğun ve yoksunluğun azaltılabilmesi açısından oldukça önemlidir. Bu yönde uygulanan politikalarla kısa vadede yoksulların bütünleşmeleri ve yoksulluklarının giderilmesi sağlanmall; uzun vadede ise gelecek kuşakların yoksullaşmasına neden olabilecek olumsuzlukların önüne geçilmelidir. Yeni istihdam alanları yaratmak ve mesleki eğitim olanaklarının sağlanmasına yönelik 
düzenlemeler yapmak sürecin doğru bir şekilde yönetilmesine katkıda bulunabilir.

Gittikçe daha görünür hale gelen ve derinleşen kentsel yoksulluk, çoğunlukla kırdan kente göç etmek durumunda kalan mülksüz insanların, kentteki işgücü piyasasının olumsuz şartlarından dolayı enformel sektörlerde istihdam edilmelerine ya da uzun süreli işsiz kalmalarına yol açmaktadır. Bu bağlamda kent yoksullarını; iş imkânlarına ve kaynaklara erişememeleri, karar verme mekanizmalarından uzak kalmaları, kentin olanaklarından ve kamusal hizmetlerden yeterince yararlanamamaları, politik ve kültürel süreçlere sağlıkl bir şekilde katılamamaları gibi nedenlerden dolayı oldukça geniş bir perspektiften ele almak gerekmektedir. Bu nedenlerden kaynaklı bir sosyal dışlanmışlığın aşılması için merkezi yönetimler ile yerel yönetimler ve sivil toplum kuruluşları politikalar geliştirmelidir. Yoksulların yaşamlarının enformellikten kurtarılabilmesi için ulusal ve uluslararası duyarlılık da sürece dinamizm katacaktır.

Yakın gelecekte, kıt kaynaklar üzerindeki nüfus baskısının son aşamaya gelip ekonomik eşitsizliği derinleştireceği ve sosyal patlamalara neden olacağı açıktır. Buna kentleşme ve çevre sorunlarını, göç ve savaş tehditlerini, aynı zamanda son dönemlerde etkisini şiddetli bir şekilde hissettiren salgın hastalıkları da eklemek mümkündür. Ve görünen o ki bu tablodan ilk etkilenen kesim yoksullar olacaktır. Çözüm devletin sosyal devlet anlayışı içerisinde hareket ederek yoksul odaklı politikalara öncelik vermesidir. Ancak kararlı ve çerçevesi doğru çizilmiş yoksulluğu önleyici politikalarla gerek kırsal gerekse kentsel yoksullukla mücadele mümkün olacaktır. 


\title{
EXTENDED ABSTRACT
}

\section{Social Policy, Poverty and Urban Poverty}

\author{
Eylem Beyazit \\ Hatay Mustafa Kemal University
}

One of the most polemical areas of social policy is poverty. Poverty studies in the social policy domain and academic results show that poverty will remain for a long time a significant problem area. While debates continue between theories of the social state, of the welfare state and the new approaches of liberalism, it is known that dimension and property of poverty have changed with globalization. Urban poverty and the shifting urban poverty states, considering population that is increasingly gathered in cities, lead governments to produce and implement new public policies in terms of access effectively to public services.

Poverty is increasing in the world due to the increasing income inequalities, unemployment and economic crises. This phenomenon is reflected in the spaces of the cities with different dimensions. The poor are confined to the urban periphery and that is why they are excluded from the city. Interregional inequalities cause a flow of immigration to cities that stand out in industry, in commerce and in tourism, because of this situation the new urban poor who emerge as a result of these migrations seek solutions informally.

The main purpose of this study is to discuss poverty and urban poverty within the framework of social policy meaning. Moreover, it is essential to understand and examine the new poverty processes that will be produced in the future through urban poverty. Nowadays, the concentration of the population in urban rather than rural areas causes the urban poverty to deepen. Trying to re-understand the urban of the future through deepening urban poverty will create a reasonable basis for the establishment of inclusive social policies. The discussions on social policy and the shift of urban poverty demonstrate that urban poverty will be the main determinant of the urban of the future and urban management as a common problem area that transcends the ideological disagreement. 
In the global process, capitalism is presented as a magical order that will be the "hero" of all humanity in the future as it is current. The magic of capitalism is here: "I create the problem, but just I will solve it. And while solving, I add "value" to humanity, and this value is a progress." Capitalist system has this point of view also in struggling with poverty. This determinacy of capitalism is not new to the habit of looking at the problem from its own perspective. What is important here is whether capitalism can reconsider itself through poverty, and how it will happen.

Urban poverty, which has become more visible and deepened, leads to the employment of property less people, who have to migrate mostly from rural to urban, in informal sectors or leads to prolonged unemployment for a long time due to the adverse conditions of the labour market in the city. In this context, it should be considered the urban poor from a very broad perspective; due to the reasons such as not having access to job opportunities and resources, staying away from decision-making mechanisms, not being able to benefit adequately from the public services, and not being able to participate in political and cultural processes. To overcome a social exclusion caused by these reasons, central administrations, local governments and non-governmental organizations should develop social policies together.

Undoubtedly in a short time, the population pressure on scarce resources will deepen economic inequality and cause social explosions. It is possible to add urbanization and environmental problems, migration and war threats, as well as pandemic diseases that have had a severe effect recently. It seems that the first segment affected by this picture will be the poor. The solution is to give priority to poor-oriented policies by acting within the perceptive of the social state. In such a way, it will be possible to fight both rural and urban poverty with determined and well-defined policies to prevent poverty. The evident visibility of poverty makes it necessary to determine the processes and dynamics of poverty and to develop social policies within this framework. In order to respond the essential needs of the poor, it is necessary for the solution of the problems that to give importance to the demands for the development of human resources rather than to the distribution of temporary aid. In the context of Giddens approach (2001), which suggests "investing in human capital whenever possible", social policies aimed at imp- 
roving human capital are very important in terms of reducing poverty and deprivation.

\section{Kaynakça / References}

Adaman, F. ve Keyder, Ç. (2005). Türkiye'de büyük kentlerin gecekondu ve çöküntü mahallelerinde yaşanan yoksulluk ve sosyal dişlanma. Avrupa Komisyonu Çalışma, Sosyal İşler ve Fırsat Eşitliği Dairesi Sosyal İçerme Belgesi Raporu, 12.09.2019 tarihinde https:/ec.europa.eu/employment_social/social_inclusion/docs/2006/stu dy_turkey_tr.pdf adresinden erişildi.

Aktan, C. C. (2002). Yoksullukla mücadele stratejileri. Ankara: Hak-İş Yayınları.

Aldemir, Ş. ve Özpınar, Ö. (2004). Kapitalizm, yoksulluk ve sosyal dişlanma, Amme İdaresi Dergisi, 37(2), 1-11.

Aybar, M. A. (2002). Marksizm ve sosyalizm üzerine düşünceler. İstanbul: İletişim Yayınları.

Bauman, Z. (1999). Çalışma, tüketicilik ve yeni yoksullar. Ü. Öktem (Çev.), İstanbul: Sarmal Yayınevi.

Beyazıt, E. (2019). Hatay kent kimliği. Ankara: Detay Yayıncılık.

Beyazıt, E. ve Güneş, M. (2016). Yeni yerel yönetim yasalarının sosyal politikaya katk1ları, International Journal of Academic Value Studies, 2(4), 78-89.

Bıçkı, D. (2005). Kentsel yoksulluğun yapısal faktörlerle analizi: ekonomik ve politik yapının yeniden örgütlenmesi; karşılaştırmalı bir analiz, İş Güç Elektronik Endüstri İlişkileri ve Insan Kaynakları Dergisi, 7(1), 104-138.

Bilsel, S.G., Polat, E., Çalışır, S. ve Hovardaoğlu, O. (2002). Kentsel yoksulluk/yoksulluğun değişik tanımları ve boyutları üzerine. Yoksulluk, Kent Yoksulluğu ve Planlama, 8 Kasım Dünya Şehircilik Günü 26. Kolokyumu, Ankara: TMMOB Şehir Plancıları Odası, 193-197.

Bostanoğlu, Ö. (2002). Küresel kent yoksulluğu ve avrupa'daki türkler. Yoksulluk, Kent Yoksulluğu ve Planlama, 8 Kasım Dünya Şehircilik Günü 26. Kolokyumu, Ankara: TMMOB Şehir Plancıları Odası, 333-359.

Buğra, A. (2008). Kapitalizm, yoksulluk ve Türkiye'de sosyal politika. İstanbul: İletişim Yayınları.

Buğra, A. ve Keyder, Ç. (2003). Yeni yoksulluk ve Türkiye’nin refah rejimi. Birleşmiş Milletler Kalkınma Programı İçin Hazırlanan Proje Raporu, 12.09.2019 tarihinde https://www.tr.undp.org/content/dam/turkey/docs/povreddoc/UNDPTR-new_poverty.pdf adresinden erişildi. 
Buğra, A. ve Keyder, Ç. (2008). Sosyal politika yazıları. İstanbul: İletişim Yayınları. Castells, M. (1997), Kent, sınff, iktidar. A. Erendil (Çev.), Ankara: Bilim ve Sanat Yayınları.

Chossudovsky, M. (1999). Yoksulluğun küreselleşmesi. N. Domaniç (Çev.), İstanbul: Çivi Yazıları.

Çolak, A. (2019). Sosyal politikanın uluslararası taraflarından uluslararası çalışma örgütü ve küreselleşme, Balkan ve Yakın Doğu Sosyal Bilimler Dergisi, 5(1), 73-84.

Çolakoğlu, E. (2003). Kentsel yoksulluk. Yerel ve Kentsel Politikalar, M. A. Çukurçayır-A. Tekel (Ed.), Konya: Çizgi Kitabevi.

Devlet Planlama Teşkilatı. (2001). Sosyal hizmetler ve yardımlar özel ihtisas komisyonu raporu. Ankara: DPT Yayınları.

DiNitto, D. M. (1991). Social welfare: Politics and public policy. Englewood Cliffs, New Jersey: Prentice Hall.

Duman, F. (2017). Durumsal muhafazakârlık anlayışı üzerine teorik \& eleştirel bir değerlendirme, Hitit Üniversitesi Sosyal Bilimler Enstitüsü Dergisi, 10(2), 797-818.

Erdem, T. (2003). Yoksulluk üzerine sosyolojik bir çalı̧ma "Ankara kent yoksulları", Yayınlanmamış Doktora Tezi, Hacettepe Üniversitesi Sosyal Bilimler Enstitüsü Sosyoloji Anabilim Dall, Ankara.

Erder, S. (2002). Kentsel gerilim. Ankara: Um:ag Vakfı Yayınları.

Erdoğan N. (2007). Yoksulluk halleri-Türkiye'de kent yoksulluğunun toplumsal görünümleri. İstanbul: İletişim Yayınları.

Erdoğan, M. (1998), Liberal toplum liberal siyaset. Ankara: Siyasal Kitabevi.

Ergun, C.-Gül, H. ve Sallan Gül, S. (2013). Neoliberal küreselleşme ve küresel kent. C. Ergun-M. Güneş-A. D. Ergun (Ed.), Kent Üzerine Özgür Yazılar, içinde İstanbul: Bağlam Yayınları.

Esin, P. (1982). İş bölümü, yabancllaşma ve sosyal politika. Ankara: Ankara Üniversitesi Siyasal Bilgiler Fakültesi Yayını.

Giddens, A. (2001). Üçüncü yol ve eleştirileri. Ankara: Phoenix Yayınevi.

Gül, H. ve Sallan Gül, S. (2004). Ekonomik krizler karşısında ankaralı yoksulların yaşam stratejileri, Dünya Şehircilik Günü 28. Kolokyumu: Değişen - Dönüşen Kent ve Bölge, ODTÜ, Ankara.

Gül, H. ve Sallan Gül, S. (2007). Sosyal devletten çalışma refahına geçişte sosyal haklar ve yoksullar, Amme İdaresi Dergisi, 40(3), 1-30.

Gül, H. ve Sallan Gül, S. (2008). Yoksulluk ve yoksulluk kültürü tartısmaları. N. Oktik (Ed.), Türkiye'de Yoksulluk Çalı̧̧maları, İzmir: Yakın Kitabevi. 
Güven, S. (1996). Toplum politikası yazıları. Bursa: Ezgi Kitabevi Yayınları.

Güven, S. (2001). Sosyal politikanın temelleri. (3. bs.), Bursa: Ezgi Kitabevi Yayınları.

Heywood, A. (2013). Siyasi ideolojiler. A. K. Bayram, Ö. Tüfekçi, H. İnaç, Ş. Akın, B. Kalkan (Çev), (5. bs.) Ankara: Liberte Yayıncılık.

Işık, O. ve Pınarcioğlu, M. M. (2018). Nöbetleşe yoksulluk:Sultanbeyli örneği.İstanbul: İletişim Yayınları.

Jargowsky, P. ve Bone, M.J. (1990). Ghetto poverty: basic questions. L. E. Lynn M. G.H. McGeary (Ed.) Inner- City Poverty in The United States, Washington D.C: National Academy Press, 16-55.

Kaygalak, S. (2001). Yeni kentsel yoksulluk, göç ve yoksulluğun mekânsal yoğunlaşması: mersin/demirtaş mahallesi örneği, Praksis, 2, 124-172.

Koray, M. ve Topçuoğlu, A. (1995). Sosyal politika. Bursa: Ezgi Kitabevi Yayınları. Lewis, O. (1971). Sanchez'in çocukları. L. Ragıp (Çev.), İstanbul: e Yayınları.

Malthus, T. (1998). An Essay on the Principle of Population an Essay on the Principle of Population, London: Electronic Scholarly Publishing Project.

Özbek Sönmez, İ. (2002a). Türkiye metropollerinde gettolaşma eğilimleri, Yoksulluk, Kent Yoksulluğu ve Planlama, 8 Kasım Dünya Şehircilik Günü 26. Kolokyumu, Ankara: TMMOB Şehir Plancıları Odası, 459-466.

Özbek Sönmez, İ. (2002b). Yoksulluğu sürekli kılan faktörler üzerine gözlemler izmir kent merkezi tarihi konut alanı örneği, Kentleşme, Göç ve Yoksulluk, 7. Ulusal Sosyal Bilimler Kongresi, Ankara: İmaj Yayınevi, 247-268.

Özbudun, S. (2002). Küresel bir yoksulluk kültürü mü? Y. Özdek (Ed.), Yoksulluk, Şiddet ve Insan Hakları, TODAİE İnsan Hakları Araştırma ve Derleme Merkezi, Yayın No: 311, Ankara: TODAİE Yayınları.

Özdek, Y. (Ed) (2002). Yoksulluk, şiddet ve insan hakları.Ankara, TODAİE Yayınlar1, Yayın No: 311.

Rawls, J. (1985). A theory of justice, England: Oxford University Press.

Recife Declaration. (1996). United Nations centre for human settlements (Habitat) the recife declaration. Urban Poverty: A World Challenge, Recife International Meeting on Urban Poverty, 17-21 March 1996, Recife: Brazil.

Sallan Gül, S., Gül, H. ve Ergun, C. (2003). Türkiye' de yoksulluk kültürü tezlerine bakış: ankara örneği. Yoksulluk ve Sosyal Hizmetler, Sosyal Hizmet Sempozyumu, 9-11 Ekim 2003, Antalya. 
Sallan Gül, S. (2002). Türkiye'de yoksulluk ve yoksullukla mücadelenin sosyolojik boyutları: göreliden mutlak yoksulluğa. Y. Özdek (Ed.), Yoksulluk, Şiddet ve İnsan Hakları, TODAİE İnsan Hakları Araştırma ve Derleme Merkezi, Yayın No: 311, Ankara: TODAïE Yayınları.

Sallan Gül, S. (2006). Sosyal devlet bitti yaşasın piyasa!, Ankara: Ebabil Yayınları.

Sen, A. (2000). Social exclusion: concept, application and scrutiny, Asian Development Bank, Social Development Papers No: 1, Manila- Philippines.

Şenses, F. (2006). Küreselleşmenin öteki yüzü yoksulluk. İstanbul: İletişim Yayınları.

Spencer, H. (2016). Devlete karşı insan. Y. S. Altındal (Çev.), İstanbul: Litera Yayınları.

Talas, C. (1992). Türkiye'nin açıklamalı sosyal politika tarihi. Ankara: Bilgi Yayınevi.

Tekeli, İ. (2000). Kent yoksulluğu ve modernite'nin bu soruya yaklaşım seçenekleri üzerine. A. H. Akder - M. Güvenç (Der.), Devlet Reformu, Yoksulluk, Bölgesel Gelişme ve Kırsal Yoksulluk-Kent Yoksulluğu (s.139-160)., İstanbul: TESEV Yayınları,

Türk Sanayicileri ve İş Adamları Derneği. (2000). Türkiye'de bireysel gelir dağılımı ve yoksulluk-Avrupa Birliği ile karşılaştırma. TÜSİAD Yayınları Yayın No: TÜSİAD-T/2000-12/295), İstanbul: Lebib Yalkın Yayımları.

Ünsal, F. (2002). Toplumsal barışın korunması bağlamında kent yoksulluğunun çağdaş kentsel dinamikler çerçevesinde değerlendirilmesi. Yoksulluk, Kent Yoksulluğu ve Planlama, 8 Kasım Dünya Şehircilik Günü 26. Kolokyu$m u$, Ankara: TMMOB Şehir Planciları Odası, 55-72.

World Development Report-2000/2001. (2001). Attacking poverty. World Development Report, New York: Oxford University Press.

\section{Kaynakça Bilgisi / Citation Information}

Beyazıt, E. (2020). Sosyal politika, yoksulluk ve kent yoksulluğu. OPUSUluslararası Toplum Araştırmaları Dergisi, 16(30), 2966-2993. DOI: 10.26466/opus.708198 